\title{
POSTOPERATIVE PAIN AND STRESS RESPONSE: DOES CHILD'S GENDER HAVE AN INFLUENCE?
}

\author{
Marijana Karišik ${ }^{1}$, Najdana Gligorović Barhanović 2 Tatjana Vulović ${ }^{3,4}$ and Dušica Simić S $^{5,6}$ \\ ${ }^{1}$ Department of Anesthesiology, Institute for Children's Diseases, Clinical Centre of Montenegro, \\ Podgorica, Montenegro; ${ }^{2}$ Centre for Clinical Laboratory Diagnostics, Clinical Centre of Montenegro, \\ Podgorica, Montenegro; ${ }^{3}$ School of Medicine, University of Kragujevac, Kragujevac, Serbia; \\ ${ }^{4}$ Centre for Anesthesiology and Resuscitation, Clinical Centre Kragujevac, Kragujevac, Serbia; \\ ${ }^{5}$ School of Medicine, University of Belgrade, Belgrade, Serbia; ${ }^{6}$ University Children's Hospital, Belgrade, Serbia
}

SUMMARY - Surgical procedure causes multisystem stress response reactions. The aim of this study was to assess whether gender has an impact on the level of neuroendocrine response to surgical stress and intensity of postoperative pain in children undergoing inguinal hernia repair surgery, as well as satisfaction of their parents with preoperative and postoperative care. The study included 60 children aged 3-6 years, all of them the only child in the family. All children included in the study were categorized as American Society of Anesthesiologists PS Class I, and divided into two groups: group 1 composed of 30 boys and group 2 composed of 30 girls. After oral premedication with midazolam, general anesthesia with endotracheal intubation was performed in all patients. Ketorolac, $1 \mathrm{mg} \cdot \mathrm{kg}^{-1}$, was administered for postoperative analgesia. Serum cortisol was measured in all children preoperatively and postoperatively. The quality of postoperative analgesia was evaluated by Wong-Baker (FACES) scale, along with parental satisfaction. Male children who were the only child in the family had stronger neuroendocrine response to surgical stress and stronger intensity of postoperative pain. The parents of the girls expressed greater satisfaction with preoperative and postoperative care.

Key words: Child; General surgery; Anesthesia and analgesia; Pain, postoperative

\section{Introduction}

Surgical trauma produces endocrine, metabolic, hematologic and immune reactions as a result of sympathetic activation ${ }^{1}$. Children are particularly vulnerable to the global surgical stress response because of limited energy reserves, larger brain masses and obligatory glucose requirements ${ }^{2}$. In children, surgical procedures are related to the effects of many stressors, such as emotional factors (fear of the unknown, separation from parents, parents' confusion, panic), pain, reduced effective circulating volume, hypoxemia, hypercarbia, changes in blood $\mathrm{pH}$, surgical manipulation,

Correspondence to: Marijana Karišik, MD, Ulica Steva Boljevića 14/17, 81000 Podgorica, Montenegro

E-mail: marijana.karisik@gmail.com

Received February 8, 2018, accepted May 16, 2018 wound tissue hypoxia, tissue destruction (tissue kneading, local circulation disorder), entrance of bacteria into the wound, administration of various chemical substances (drugs), fasting, changes in body temperature, etc. ${ }^{2-4}$. The body responds to surgical procedure with a whole series of protection and adaptation mechanisms such as psycho-emotional, neurovegetative, neuroendocrine, immune, metabolic, hematopoietic, hydroelectrolyte and acid base changes ${ }^{2-4}$. All these protection mechanisms are intended to maintain homeostasis and to re-establish the physiological balance $^{2,4}$. The surgical stress response is initiated by neuronal activation of the hypothalamus-pituitary-adrenal axis, and causes increase in endogenous catecholamines and glucocorticoids ${ }^{4-6}$. The release of inflammatory mediators from the surgical site may also be responsible for the development of stress response due to activation of the hypothalamus-pituitary-adrenal axis ${ }^{1-4}$. 
For a long time, it was believed that children, especially infants, did not feel pain, and the use of local and systemic analgesics was considered harmful ${ }^{7-10}$. Today, we know that even before birth, in humans there are all conditions for the perception of pain and that the fetus responds to physiological painful stimulation ${ }^{7}$.

The first nociceptors appear in the area of the mouth and face already in the $7^{\text {th }}$ week of pregnancy and until the $20^{\text {th }}$ week they cover the entire body. At the same time, functional reflex circuits of spinal cord are developing. A higher brain pathway includes a spinothalamic pathway that develops around the $20^{\text {th }}$ week and becomes completely myelinated until the $29^{\text {th }}$ week. Thalamic cortical pathways begin to be part of the somatosensory cortex between the $22^{\text {nd }}$ and $26^{\text {th }}$ week of pregnancy. This means that after $26^{\text {th }}$ week of gestation, neuroanatomic conduct pain pathways have been developed ${ }^{11}$.

Assessment of pain in children is done through various clinically applicable pain scales ${ }^{12}$. It is very difficult to predict a child's reaction to hospital stay and it mostly depends on the child's age and his/her cognitive abilities ${ }^{2,5,8,13-15}$.

There are indicators and deduction in opinions and research evidence, based on the specifics of the child's psychology, that boys are more vulnerable than girls to hospital stay and that mothers of boys openly show great concern, considering that the Balkans is commonly associated with a propensity to chauvinist separatism $^{14,16,17}$.

The aim of the study was to examine the influence of gender of an only child in the family in Montenegro following planned unilateral inguinal hernia repair surgery on changes in neuroendocrine response to surgical stress and intensity of postoperative pain, as well as the degree of parental satisfaction with hospital stay and treatment.

\section{Patients and Methods}

The study lasted for 12 months and was approved by the Ethics Committee of the Clinical Centre of Montenegro. Inclusion criteria were consecutive female and male patients aged 3-6 years over a one-year period, all of them the only child in the not divorced family, scheduled for elective unilateral inguinal hernia repair and with no comorbidities (American Society of Anesthesiologists PS Class 1, ASA PS 1) (Fig. 1). The

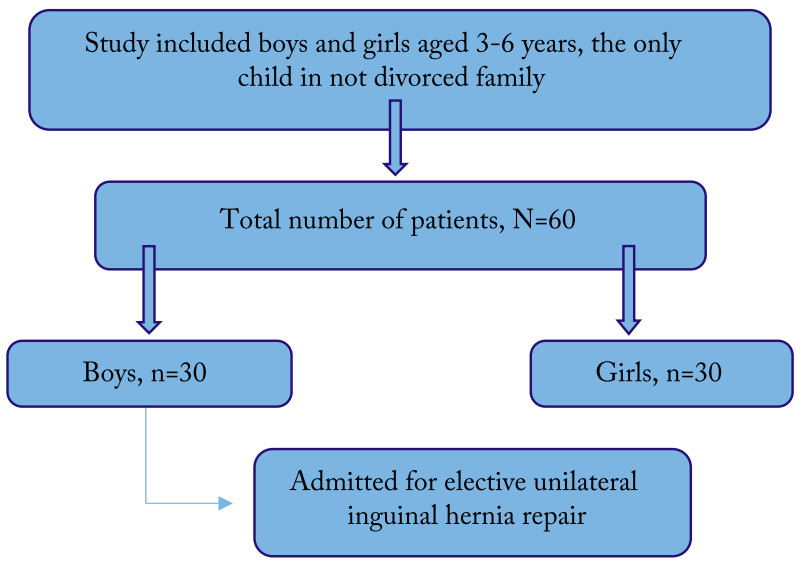

Fig. 1. Flowchart with details of patient recruitment.

patients were assessed on the day before surgery, in accordance with our institution protocol. An informed consent was obtained from parents of study patients. Surgeries were performed between 8 a.m. and 11 a.m. in order to avoid circadian changes of stress hormones. All children received oral premedication with midazolam $0.5 \mathrm{mg} \cdot \mathrm{kg}^{-1} 30$ minutes before the surgery.

Group 1 was composed of 30 male children, all of them the only child in the family. Group 2 was composed of 30 female children, all of them also the only child in the family. All patients were monitored by three-lead electrocardiography (ECG), pulse oximetry, noninvasive blood pressure and capnography. A warming blanket was used to prevent hypothermia during surgery.

Both groups of patients received a standardized protocol of general anesthesia with endotracheal intubation and postoperative analgesia. General anesthesia induction was performed by intravenous administration of atropine $0.1 \mathrm{mg} \cdot \mathrm{kg}^{-1}$, propofol $2.5 \mathrm{mg} \cdot \mathrm{kg}^{-1}$, fentanyl $1 \mathrm{mcg}^{-1}$, and rocuronium $1 \mathrm{mg} \cdot \mathrm{kg}^{-1}$. After direct laryngoscopy, an uncuffed tube of appropriate size was placed in the trachea. Anesthesia was maintained with fentanyl $2 \mathrm{mcg} \cdot \mathrm{kg}^{-1}$ and sevoflurane in MAC 2.8\% for 3-year-old children, and 2.5\% for 4-, 5- and 6-yearold children. Patients were ventilated with a mixture of oxygen and air (40\%:60\%). At the end of surgery, ketorolac $1 \mathrm{mg} \cdot \mathrm{kg}^{-1}$ was administered for postoperative analgesia. Endotracheal tube was removed when the patients achieved satisfactory spontaneous breathing. Neuromuscular monitoring (train of four) is used with administration of neostigmine $0.05 \mathrm{mg} \cdot \mathrm{kg}^{-1}$ and atropine $0.02 \mathrm{mg} \cdot \mathrm{kg}^{-1}$ to antagonize residual neuromuscu- 
lar block. After the end of surgery, upon awakening from anesthesia, all patients, boys and girls, were transferred to the pediatric surgical ward with their mothers, in accordance with our institution's protocol (mothers stay with their children in the hospital, or if it is impossible, then a grandmother or aunt, but only females). Parents were asked about waiting time related to admission, information obtained about care and treatment, nurses' behavior and communication between physicians and parents by anesthesia trainees in our department in the form of a questionnaire.

\section{Measurements}

Baseline value of serum cortisol was recorded before premedication at $8 \mathrm{a} . \mathrm{m}$. and postoperatively at 6 p.m. for evaluation of stress response on the day of surgery. Assessment of postoperative pain was performed using Wong-Baker (FACES) scale postoperatively after 2, 4, 8 and 12 hours (Fig. 2).

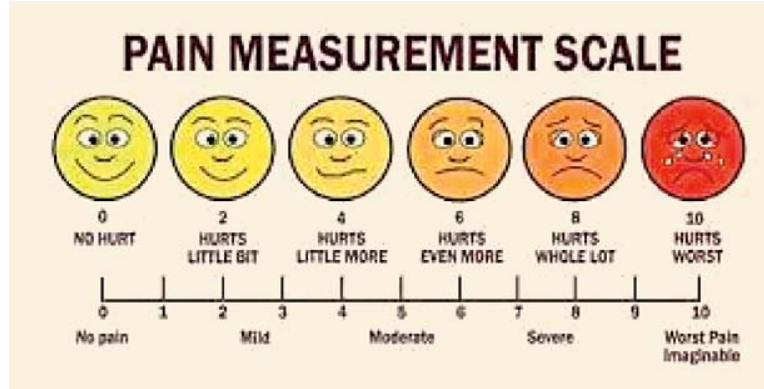

Fig. 2. Wong-Baker scale for pain assessment in two study groups.
The degree of the parents' satisfaction was estimated using a three-point scale (dissatisfied $=1$, neither satisfied nor dissatisfied $=2$, satisfied $=3$ ).

\section{Statistics}

Calculation of the sample size was based on the results of other similar studies. PC software was used to estimate the size of the sample (http://ps-powerand-sample-size-calculation.software.informer.com/). Based on those values, the power of the study of $80 \%$ was obtained, necessary to analyze 24 patients in both groups to detect a difference at $5 \%$ significance level. We used the statistical program SPSS for Windows 19.0 and STATISTICA 5.0 for statistical analysis. Quantitative data were described as mean and standard deviation, and independent sample t-test was used for comparison between the groups. Categorical data were described as proportion, and $\chi^{2}$-test was used for comparison between the groups. The level of statistical significance was set at $\mathrm{p}<0.05$.

\section{Results}

According to demographic data, both study groups were comparable with respect to gender and age. There was a nonsignificant age difference between the study groups (4.27 \pm 2.16 vs. $4.16 \pm 2.15)$ (Table 1 ).

Preoperative morning serum cortisol levels, used as baseline values, were compared with postoperative afternoon values, and were statistically significantly higher in group 1 (boys-units) than in group 2 (girlsunits) (Table 1).

Table 1. Age and serum cortisol levels in two study groups

\begin{tabular}{|l|l|l|l|}
\hline & Group 1 & Group 2 & p value (95\% CI) \\
\hline Age (years) & $4.27 \pm 2.16$ & $4.16 \pm 2.15$ & $0.858(-1.22 ; 1.02)$ \\
Cortisol $(\mathrm{nmol} / \mathrm{L})$ before surgery & $12.27 \pm 2.32$ & $13.13 \pm 2.16$ & $0.140(-2.03 ; 0.29)$ \\
Cortisol (nmol/L) after surgery & $18.30 \pm 1.53$ & $15.03 \pm 1.56$ & $<0.001^{*}(2.47 ; 4.07)$ \\
\hline
\end{tabular}

$\mathrm{CI}=$ confidence interval; ${ }^{*} \mathrm{p}<0.05$ comparing both groups

Table 2. Parental satisfaction in two study groups

\begin{tabular}{|l|l|l|l|}
\hline Parental satisfaction & Group 1 & Group 2 & p value (95\% CI) \\
\hline Dissatisfied & $6(20 \%)$ & $0(0 \%)$ & $0.009^{*}$ \\
Neither satisfied nor dissatisfied & $10(33.33 \%)$ & $6(20 \%)$ & 0.242 \\
Satisfied & $14(46.67 \%)$ & $24(80 \%)$ & $0.007^{*}$ \\
\hline
\end{tabular}

$\mathrm{CI}=$ confidence interval; ${ }^{*} \mathrm{p}<0.05$ comparing both groups 


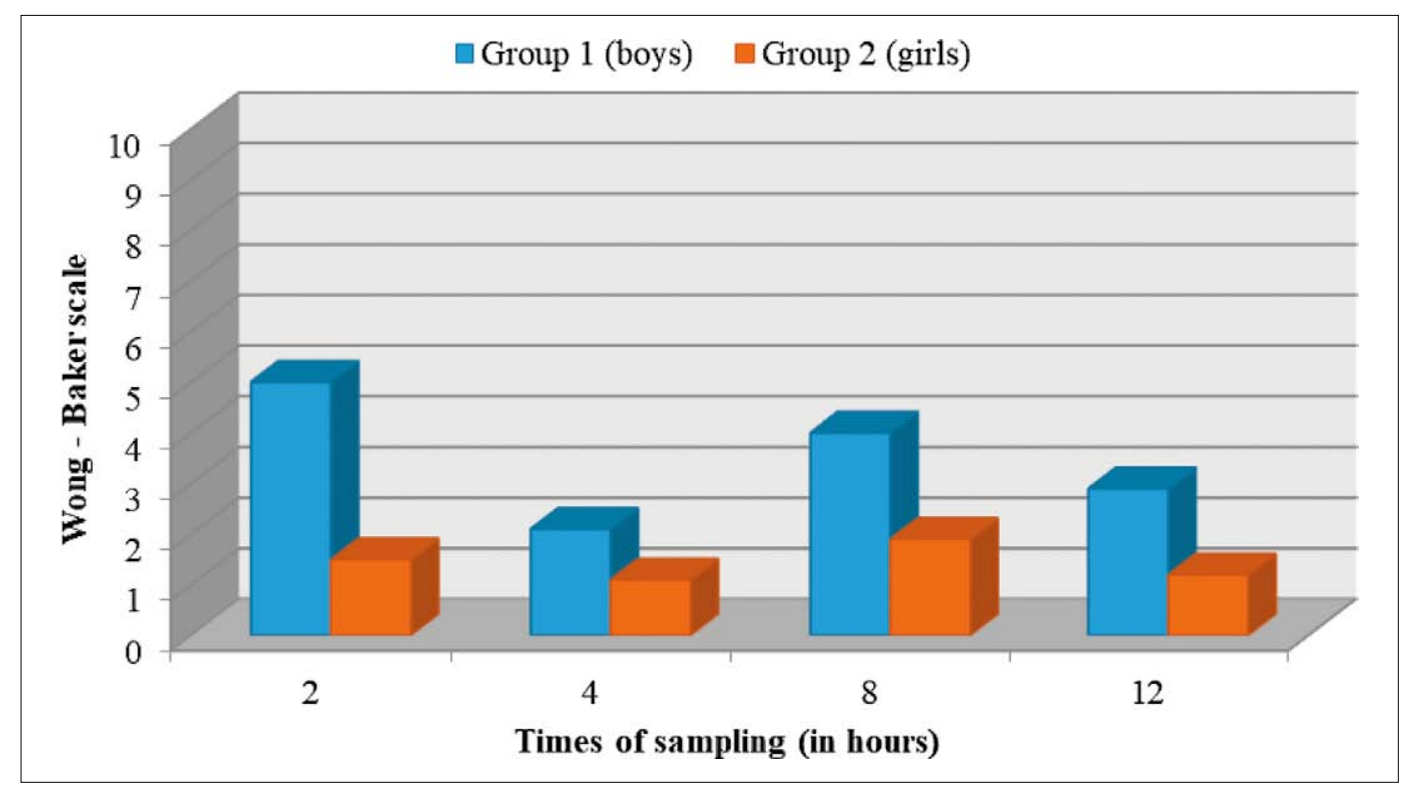

Fig. 3. Postoperative pain scores.

There were 14 satisfied parents of group 1 patients as compared to 24 satisfied parents of group 2 patients. There were six dissatisfied parents in group 1 and none dissatisfied parent in group 2 (Table 2).

Postoperative pain level measured with WongBaker (FACES) scale was significantly higher in group 1 than in group 2 after 2, 4, 8 and 12 hours (Fig. 3).

\section{Discussion}

Anesthesia related gender differences have been identified in adults but in children have not been well documented. Can gender influence postoperative stress response of the child's body? Our study showed the influence of male gender in the category of family with only one child on modification of neuroendocrine stress response, by measuring serum cortisol levels. Significantly higher serum cortisol levels were recorded postoperatively in the group of boys, who were the only child in the family. Neuroendocrine response to stress and activation of the hypothalamic-pituitaryadrenal axis are known to lead to increased secretion of endogenous catecholamines and glucocorticoids ${ }^{1-4,6}$. The most important causes of stress in surgical patients are pain, fear and tissue destruction ${ }^{2-4}$.

Pain is an important stimulus response and reaction of the nervous system to precipitating agents ${ }^{2,3,7,18}$. The nociceptor (pain receptor) responds to a painful stimulus. Then, the impulse is transmitted by afferent neurons in the hypothalamus stimulating the hypothalamic-adrenal axis, and then through it stimulating the adrenal glands to secrete cortisol. Cortisol is considered the most important mediator of stress response. Its concentration in the blood correlates very well with stress intensity ${ }^{1-4,6,7}$.

Emotional factors such as anxiety, fear, pressure and excitement are powerful stimuli of neuroendocrine response, and lead to an increase in cortisol levels in the blood ${ }^{2-4,6,8,13}$. Social and psychological factors such as hospital stay and medical procedures, anxiety due to separation from parents justify the use of pre-

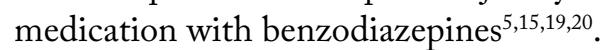

Midazolam is a commonly used drug for premedication. Midazolam induces sedation, reduces anxiety, induces anterograde amnesia, facilitates separation from parents, reduces baseline metabolic rate and thus the total amount of anesthetic required, and facilitates induction of anesthesia. In addition, recent literature shows that midazolam decreases secretion of cortisol ${ }^{5,19,20}$.

Surgical incision is the major stimulus and initiator in stress response ${ }^{1-4,18}$. In major surgical procedures, stress of the body caused by tissue destruction is greater. Tissue destruction during surgical procedures triggers the inflammation system and activates self defense of the body ${ }^{1-4}$. The mediators that are released at the same time affect neuroendocrine reflexes ${ }^{2,3}$. 
The role of the anesthesiologist is to adapt anesthesia procedures to physiological processes in the body, as to achieve that stressors exhaust the body adaptation abilities to the least possible extent.

On the other hand, stress caused by hospital stay is relieved by providing a sense of security ${ }^{5,14-25}$. The role of parents is to provide this sense of security to their child $8,15,16,24$. The role of medical team (psychologists, physicians and nurses) is to provide the sense of security and confidence to the parents. The parents' task is to follow instructions given by medical team, which are the key for successful treatment of their child during hospital stay ${ }^{14}$.

Providing a sense of security to quivering parents of an only child, especially male child, who are filled with fear and doubt concerning medical staff and hospital stay is a challenge. According to developmental psychology of children, there are specific and individual differences during growth and development among children. According to literature data, extreme anxiety during induction of anesthesia in children is associated with an increase of postoperative negative behavioral changes ${ }^{5,20,23-26}$. Correlation was found between postoperative agitation and anxiety level of parents, as well as mood, behavioral and sleep disturbances in children $^{20}$. According to the Montenegrin culture, tradition and folklore, male children are more appreciated, being carriers of the family name and more protected than female children, so husband expects to have a son and if the wife does not give birth to a male child, she is less valuable ${ }^{17,27}$. Considering the position the Montenegrin women had in the past and comparing it with the $21^{\text {st }}$ century reveals that it must have caused some stereotypes, and the Balkans makes a perfect soil for their growth ${ }^{17,27}$. The past situation of women was quite complicated to explain. One might say they were nothing more than shadows of men closest to them, but there is more. Like many other countries, they had various laws concerning this and men who violated those laws were considered a disgrace to the family and the society, for the given word in Montenegro was respected most $^{27}$. Because those rules were not written, we discover them by studying epics and songs left from that period, (un)fortunately, there is no better proof of their life. But were those laws really that good when so many people believed women were somewhat worthless? Yes, that would be the result of all the stereotypes that appeared in who knows how many ways ${ }^{27}$.
So, let's finally explain those laws determining the 'terrible' position of Montenegrin women. Rule number one: one who kills woman has committed a fatal crime and will bring shame to their name for as long as they live. Women had what men thought they needed most at that time, i.e. protection. It was a patriarchal society, so of course, men made the laws, but they were very considerate of what they thought women needed most. Father would marry his daughter to the one that made the biggest effort to win her over, she was precious to him and he would not want her be with someone who could not provide good life to her ${ }^{27}$.

Now, a girl would never go back to her family after marriage except for two cases, i.e. if she could not conceive or had cheated on her husband. These were reasonable reasons, for they all wanted a loyal wife that would give them heirs and continue their bloodline. Yes, women were not allowed to leave the house unless a man close to her accompanied her, but it was believed to be for her own good. Who knows what might happen if a woman walked around the town alone, without anyone who could protect her if something happened; besides, the husband would not like that someone thought she was not married yet, as it would cause some conflict that was not wanted (especially because Montenegrins were known for being impulsive $)^{27}$.

In addition, women were not allowed to show emotions in front of other people, but guess what, neither were men. Nothing was as it may have seemed to be. Not all stereotypes should be believed. Women had to obey their men's will, who thought they knew what was best for them. Women were recognized by the name of their brother, father or husband, which caused them to lose some of their identity but nothing can be perfect. People do what they think is best, leaving scars or not. It is good if it does not but when you live in a country as small as Montenegro where people had the same way of life for centuries, it surely leaves a mark; mentality and conservativeness of people is terribly hard to change, but it is changing inevitably.

According to child psychology during growth, every child goes through many different periods that characterize some of their cognitive abilities ${ }^{9,14-16}$. They are shown through child's understanding of disease, their reaction to the hospital, its staff and hospitalization, which is for children emotionally draining, mostly due to change of the environment ${ }^{14}$. Additionally, 
young children (5-7 years) believe that illness is a punishment for their bad behavior. In the process of child's hospitalization, the main role is played by their parents and hospital staff that try to calm down and encourage them by talking about diverse topics ${ }^{14}$. This is important if one wants to avoid emotional traumas as side effects. The causes of stress that affect the child's psyche while they are in the hospital are as follows ${ }^{14}$ : a) unknown surroundings, b) unclear expectations and boundaries, c) loss of control, d) symptoms of sickness, and e) uncomfortable diagnostic and therapeutic procedures.

The level of stress can be lowered by respecting the child's wishes, giving clear and precise information, allowing the child to take part in the process of recovering, and the most important thing is giving them the sense of security ${ }^{14}$.

According to the results of our study, there was a significantly greater need for analgesics after surgery in boys than in girls, and significantly greater satisfaction of parents of the girls after surgery versus significantly greater dissatisfaction of parents of the boys after surgery.

\section{Conclusion}

Preoperative high parental anxiety was found to be related to increased anxiety in children not only during the surgical procedure but also in the postoperative period. The reasons for this were specific differences in cognitive growth of a child, i.e. causes that led to changes in their behavior, causal connections between the child's genetics, social and physical surroundings, and their way of acting. We determine the main characteristics of a particular culture in general by observing the way the society accepts and educates children. A change of attitude towards those children could explain many other macrosocial alterations in the structure and function of a family, for example. The period of patriarchal society in the past caused some stereotypes and makes a good soil for that.

According to study results, mothers of boys openly showed great concern, anxiety, fear and more complains related to perioperative management, admission and accommodation during hospital stay than mothers of girls did; the latter were calm, cooperative and mostly satisfied. Boys who were the only child in the family were more vulnerable, more fearful, more ner- vous, had stronger neuroendocrine response to surgical stress, and stronger intensity of postoperative pain than girls, who were the only child in the family as well and had undergone the same surgical procedure.

The study confirmed the need of psychological preparation of parents before elective surgery procedure in their children to improve the mother-child relationship, so that they could contribute constructively during hospitalization because according to development of the nocioceptive system, there is no reason for boys and girls to react differently to postoperative pain.

\section{References}

1. Colombo R, Raimondi F, Corona, Rivett I, Pagani F, Porta VD, et al. Comparison of the Surgical Pleth Index with autonomic nervous system modulation on cardiac activity during general anaesthesia: a randomized cross-over study. Eur J Anaesthesiol. 2014;31:76-84. DOI: 10.1097.EJA.0000436116.06728.b3

2. Desborough JP. Physiological responses to surgery and trauma. J Br Anaesth. 2000;85:109-17. DOI: 10.1093.BJA.85.1.109

3. Charmandari E, Kino T, Souvatzoglou E, Chrousos GP. Pediatric stress: hormonal mediators and human development. Horm Res. 2003;59:161-79. DOI: 69325

4. Singh M. Stress response and anesthesia altering the peri- and post-operative management. Indian J Anaesth. 2003;47: 427-34.

5. McCann ME, Kain ZN. The management of preoperative anxiety in children: an update. Anesth Analg. 2001;93:98-105.

6. Simons SS, Cillessen AH, de Weerth C. Associations between circadian and stress response cortisol in children. Stress. 2017 Jan;20(1):52-8.

7. Loizzo A, Loizzo S, Capasso A. Neurobiology of pain in children; an overview. Open Biochem J. 2009;3:2418-25.

8. Blount RC, Loiselle LA. Behavioral assessment of paediatric pain. Pain Res Manag. 2009;14:47-52.

9. Šervicl-Kuchler D, Maldini B, Borgeat A, Bilić N, Košak R, Mavčić B, et al. The influence of postoperative epidural analgesia on postoperative pain and stress response after major spine surgery. Acta Clin Croat. 2014 Jul;53(2):176-83.

10. Lončarić-Katušin M, Persoli-Gudelj M, Šimić-Korać N, Blažanin B, Žunić J, Korać Ž. Acute postoperative pain therapy: Current state. Acta Clin Croat. 2006 Mar;45(1):15-9.

11. Butković D. A clinical approach to the treatment of pain. Medicus. 2014;23(2):127-37.

12. Bijur PE, Silver W, Gallagher EJ. Reliability of the visual ana$\log$ scale for measurement of acute pain. Acad Emerg Med. 2001;8:1153-7.

13. Gul C, Gursoy A. The effect of preoperative distress on the perioperative period.J Anesth Inten Care Med. 2017;2:555-88. DOI: 10.19080.JAICM.2017.02.555578 
14. Kosec M. Medicinska psihologija bolesnog djeteta. Sveučilište Sjever. Odjel za biomedicinske znanosti. Završni rad br. XX/ $\mathrm{MM} / 2015$. Croatia. (in Croatian)

15. Breaux RP, Harvey EA. A longitudinal study of the relation between family functioning and preschool ADHD symptoms. J Clin Child Adolesc Psychol. 2018 Mar;26:1-16. DOI: 10.1080/15374416.2018.1437737

16. Vukojević M, Zovko A, Talić J, Tanović M, Rešić B, Vrdoljak J, et al. Parental socioeconomic status as a predictor of physical and mental health outcomes in children. Acta Clin Croat. 2017 Dec;56(4):742-8. DOI: 1020471/acc.2017.56.04.23

17. Aleksić T. The sacrificed body: Balkan community building and the fear of freedom. University of Pittsburg Press; 2013.

18. Robleda G, Sillero A, Puig T, Gich I, Banos J. Influence of preoperative emotional state on postoperative pain following orthopedic and trauma surgery. Rev Lat Am Enfermagem. 2014;22:785-91. DOI:10.1590/0104-1169.0118.2481

19. Lerman J. Preoperative assessment and premedication in paediatrics. Eur J Anaesthesiol. 2013;30:645-50. DOI: 10.1097. EJA.0b013e328360c3e2

20. Kain ZN, Caldwell-Andrews AA, Marannets I, McClain B, Gaal D, Mayes LC, et al. Postoperative anxiety and emergence delirium and postoperative maladaptive behaviors. Anesth Analg. 2004;99:1648-54.

DOI: 10.1213/01.ANE.0000136471.36680.97
21. Kazak Z, Gul BS, Ali AY, Yesim A. Premedication with oral midazolam with or without parental presence. Eur J Anaesthesiol. 2010;27:347-52.

22. Da Silva LM, Broz LG, Modolo NS. Emergency agitation in pediatric anesthesia: current features. J Pediatr. 2008;84: 107-13. DOI: 10-2223/JPED.1763

23. Isik B, Baygin O, Kapci EG, Bodur H. The effects of temperament and behavior problems on sedation failure in anxious children after midazolam premedication. Eur J Anaesthesiol. 2010;27:336-40. DOI:10.1097.EJA.0b013e32833111b2

24. Kim H, Jung SM, Yu H, Park SJ. Video distraction and parental presence for the management of perioperative anxiety and postoperative bBehavioral disturbances in children. Eur J Anaesthesiol. 2015;121:778-84.

DOI: 10.1213.ANE.0000000000000839

25. Wright KD, Sherry HS, Finley AG, Buffet JSE. Prevention and intervention strategies to alleviate preoperative anxiety in children. Sage J. 2007;31:52-79. DOI: $10.1177 / 0145445506295055$

26. Aldecoa C, Bettelli G, Bilotta F, Sanders RD, Audisio R, Borozdina $A$, et al. European Society of Anesthesiology evidencebased and consensus-based guideline on postoperative delirium. Eur J Anaesthesiol. 2017;34:192-214. DOI: 10.1097. EJA.0000000000000594

27. Bulatović A. Žene Crne Gore kroz vjekove. Beograd: Zadužbina Andrejević; 2010. (in Montenegrin)

Sažetak

\section{IMA LI SPOL DJETETA UTJECAJ NA POSLIJEOPERACIJSKU BOL I ODGOVOR NA STRES?}

\section{Karišik, N. Gligorović Barhanović, T. Vulović i D. Simić}

Kirurški zahvat uzrokuje multisistemsku reakciju organizma u odgovoru na stres. Cilj ovog istraživanja je bio procijeniti ima li spol djeteta i ponašanje roditelja utjecaj na razinu neuroendokrinog odgovora bolesnika na kirurški stres i intenzitet poslijeoperacijske boli u djece koja su podvrgnuta operaciji preponske kile. Studija je uključivala 60 djece u dobi od 3 do 6 godina, od kojih su svi bili jedino dijete u obitelji. Sva djeca uključena u studiju kategorizirana su kao klasa I. Američkog društva anesteziologa i podijeljena u dvije skupine: prvu skupinu od 30 dječaka i drugu skupinu od 30 djevojčica. Nakon oralne premedikacije midazolamom kod svih bolesnika je provedena opća endotrahealna anestezija. Ketorolak u dozi od 1 mg.kg-1 je primijenjen za poslijeoperacijsku analgeziju. Kortizol u serumu mjeren je prijeoperacijski i poslijeoperacijski. Kod sve djece provedena je procjena kvalitete poslijeoperacijske analgezije pomoću Wong-Bakerove ljestvice (FACES) i zadovoljstva roditelja. Muška djeca koja su bila jedino dijete u obitelji imala su jači neuroendokrini odgovor na kirurški stres i jači intenzitet poslijeoperacijske boli. Roditelji djevojčica bili su zadovoljniji prijeoperacijskim i poslijeoperacijskim tretmanom njihove djece.

Ključne riječi: Dijete; Kirurgija, opća; Anestezija i analgezija; Bol, poslijeoperacijska 